\title{
Production of Homozygous Transgenic Rainbow Trout with Enhanced Disease Resistance
}

\author{
Pinwen Peter Chiou • Maria J. Chen • Chun-Mean Lin • \\ Jenny Khoo • Jon Larson • Rich Holt • Jo-Ann Leong • \\ Gary Thorgarrd • Thomas T. Chen
}

Received: 15 May 2013 / Accepted: 16 September 2013 / Published online: 2 October 2013

(C) The Author(s) 2013. This article is published with open access at Springerlink.com

\begin{abstract}
Previous studies conducted in our laboratory showed that transgenic medaka expressing cecropin B transgenes exhibited resistant characteristic to fish bacterial pathogens, Pseudomonas fluorescens and Vibrio anguillarum. To confirm whether antimicrobial peptide gene will also exhibit antibacterial and anti-viral characteristics in aquaculture important fish species, we produced transgenic rainbow trout expressing cecropin P1 or a synthetic cecropin B analog, CF-17, transgene by sperm-mediated gene transfer method. About $30 \%$ of fish recovered from electroporation were shown to carry the transgene as determined by polymerase chain reaction (PCR) amplification assay. Positive $\mathrm{P}_{1}$ transgenic fish were crossed to nontransgenic fish to establish $F_{1}$ transgenic founder families, and subsequently generating $F_{2}$, and $F_{3}$ progeny. Expression of
\end{abstract}

\footnotetext{
P. P. Chiou • M. J. Chen - C.-M. Lin · J. Khoo · J. Larson •

T. T. Chen $(\bowtie)$

Department of Molecular and Cell Biology, University of Connecticut, 91 N. Eagleville Road, U-3125, Storrs, CT 06269, USA

e-mail: thomas.chen@uconn.edu
}

\section{R. Holt}

Department of Microbiology, State University of Oregon, Corvallis, OR 97331, USA

\section{J.-A. Leong}

Hawaii Institute of Marine Biology, University of Hawaii, Coconut Island, P.O. Box 1346, Kaneohe, HI 96744, USA

\section{G. Thorgarrd}

School of Biological Sciences, Washington State University, Pullman, WA 99164, USA

Present Address:

P. P. Chiou

Marine Research Station, Academia Sinica, Jiaushi, Ilan 262, Taiwan

Present Address:

J. Khoo

Environmental Protection Authority, Private Bag 63002,

Wellington 6140, New Zealand cecropin P1 and CF-17 transgenes was detected in transgenic fish by reverse transcription (RT)-PCR analysis. The distribution of body sizes among $F_{1}$ transgenic fish were not significantly different from those of non-transgenic fish. Results of challenge studies revealed that many families of $F_{2}$ and $F_{3}$ transgenic fish exhibited resistance to infection by Aeromonas salmonicida and infectious hematopoietic necrosis virus (IHNV). All-male homozygous cecropin P1 transgenic families were produced by androgenesis from sperm of $\mathrm{F}_{3}$ heterozygous transgenic fish in one generation. The resistant characteristic to $A$. salmonicida was confirmed in progeny derived from the outcross of all-male fish to non-transgenic females. Results of our current studies confirmed the possibility of producing disease-resistant homozygous rainbow trout strains by transgenesis of cecropin $\mathrm{P} 1$ or CF-17 gene and followed by androgenesis.

Keywords Cecropin P1 · Antimicrobial peptide · Transgenic rainbow trout $\cdot$ Disease resistant $\cdot$ Sperm-mediated gene transfer $\cdot$ Electroporation

\section{Introduction}

Cecropins, a family of small molecular weight basic peptides with bactericidal activity, also known as antimicrobial peptide (AMP), were first discovered in the hemolymph of diapausing cecropia (Hyalophora cecropia) pupae following inoculation with bacterial debris (Hultmark et al. 1980; Boman and Hultmark 1987). Since then many cecropin-like antimicrobial peptides have been identified and characterized from a wide variety of organisms including nematode (Pillai et al. 2005), invertebrates, vertebrates (for review, see Bulet et al. 2004) and plants (Broekaert et al. 1995). Cecropins are first translated as prepropeptides containing 62 to 64 amino acid residues, and then processed intracellularly into mature peptides of 35 to 37 amino acid residues prior to secretion into the circulation 
(Boman et al. 1991; Boman 1995). Due to their unique structural features, cecropins and cecropin-like peptides can be readily incorporated into the plasma membranes of bacteria resulting in the formation of pores on the plasma membrane and leading to the inevitable death of prokaryotic and eukaryotic pathogens (Bechinger 1997). Many cecropin analogs have been designed and synthesized, and these peptides are as effective as or even more potent than their native molecules against plant and animal bacterial pathogens and protozoa (KadononOkuda et al. 1995; Merrifield et al. 1995; Rodriguez et al. 1995; Vunnam et al. 1995). Genes (cDNAs and genomic sequences) encoding cecropins and their analogues have been cloned from insects (van Hofsten et al. 1985; Tian et al. 2010), nematode (Pillai et al. 2005), shrimp (Destoumieux et al. 1997; Chiou et al. 2005), and vertebrates (Syvitski et al. 2005). By the use of gene transfer technology, genes of cecropins and their analogues have been used to produce transgenic plants (Jaynes et al. 1987; Hassan et al. 1993; Jia et al. 1993; Huang et al. 1997; Osusky et al. 2000) with increased resistance to infection by bacterial or fungal pathogens.

Fish diseases resulting from infection by bacterial, viral and parasitic pathogens are one of the most severe bottlenecks in aquaculture (Inglis and Hendrie 1993; Thune et al. 1993). For the past few decades, efforts to control infectious diseases in commercially important fish species have primarily depended on employing antibiotics, developing suitable vaccines and selecting fish strains with robust resistance to infectious pathogens. Although control of fish diseases by using antibiotics is effective, the number of antibiotics approved for treating diseased fish infected by bacterial pathogens is limited (Post 1987). Furthermore, the increasing number of antibioticresistant pathogenic microorganisms in the aquatic environment challenges the strategy of using antibiotics to control fish diseases (Fjalestad et al. 1993). While effective vaccines have been developed for several important fish pathogens over the past many years, the current vaccination practice is expensive, laborious and time consuming (Fjalestad et al. 1993; Ganz 1999). The advantage of using vaccination technology is often out-weighed by its labor-intensiveness. Genetic selection based on traditional cross-breeding techniques is timeconsuming and the outcome is frequently unpredictable, and sometimes disappointing due to lacking the desired genetic traits. Therefore, more effective approaches for controlling fish disease in aquaculture are highly desirable.

In vitro studies previously conducted in our laboratory have shown that antimicrobial peptides such as cecropin B, cecropin P1, pleurocidin and CF-17 peptide (a synthetic cecropin B analogue) exhibited bactericidal activity to fish bacterial pathogens such as Pseudomonas flourescens, Aeromonas hydrophila and Vibrio anguillarum (Chiou et al. 2002; Sarmasik and Chen 2003; Chiou et al. 2006). Furthermore, Chiou et al. (2002) showed in in vitro studies that cecropin $\mathrm{P} 1$ and $\mathrm{CF}-17$ peptide effectively inhibited the replication of fish viruses such as infectious hematopoietic necrosis virus (IHNV), viral hemorrhagic septicemia virus (VHSV), snakehead rhabdovirus (SHRV) and infectious pancreatic necrosis virus (IPNV). Additionally, Jia et al. (2000) demonstrated the enhanced resistance to bacterial infection in fish which were continuously transfused with a cecropin-melittin hybrid peptide (CEME) and pleurocidin amide, a C-terminally amidated form of the natural flounder peptide. These results suggested that production of disease-resistant fish strain might be achieved by manipulating AMP genes. To test this hypothesis, Sarmasik et al. (2002) introduced transgene constructs containing prepro-cecropin B, procecropin B, mature cecropin B and cecropin $\mathrm{P} 1$ into the embryos of medaka by electroporation. The $\mathrm{F}_{2}$ transgenic medaka was subjected to bacterial challenges at an $\mathrm{LD}_{50}$ dose with Pseudomonas fluorescens and $V$. anguillarum, respectively. The resulting relative percent survival (RPS) of the tested transgenic $\mathrm{F}_{2}$ fish ranged from $72 \%$ to $100 \%$ against $P$. fluorescens and $25 \%$ to $75 \%$ against $V$. anguillarum, respectively.

To confirm the feasibility of producing disease-resistant fish strains by manipulating antimicrobial peptide genes in aquaculture fish species, we have transferred cecropin P1 or CF-17 transgenes, under the control of a cytomegalovirus (CMV) promoter, into rainbow trout by sperm-mediated gene transfer method. A total of eight families of cecropin P1 and nine families of CF-17 transgenic rainbow trout were established and bred to all-male homozygous. In this article, we report that the progeny of these transgene-expressing rainbow trout strains exhibited resistance to infection by Aeromonas salmonicida and IHNV.

\section{Materials and Methods}

\section{Fish Stock and Transgene Constructs}

Sperm and eggs of rainbow trout (Oncorhynchus mykiss) were obtained from Troutlodge (Sumner, WA, USA) or Roarding River Trout Hatchery (Scio, OR, USA). Fish from embryos to adulthood were reared in tanks with flow through fresh water $\left(12-15^{\circ} \mathrm{C}\right)$ in the John L. Fryer Salmon Disease Laboratory of Oregon State University (Corvallis, OR, USA). Fish were fed to satiety, once a day, with pelleted trout feed (Melick Aqua Feeds, Catawissa, PA, USA).

Cecropin P1 transgene construct was provided by Dunham et al. (2002). Briefly, the coding sequence of mature cecropin P1 cDNA fused with the signal peptide sequence of catfish immunoglobulin heavy chain (Ig) was cloned in frame into an expression vector, pRC/CMV (5.5 kb; Invitrogen, Carlsbad, CA, USA) under the control of a CMV promoter (Fig. 1). CF17 transgene construct was constructed by replacing sequence of cecropin P1 with a synthetic gene of cecropin analog (Fig. 1). 
a

\begin{tabular}{rl|l|l|} 
Procine cecropin P1 & CMV & IgG & Cecropin P1 \\
\cline { 2 - 3 } & & \multicolumn{3}{l}{} \\
\cline { 2 - 4 } & $\mathrm{CMV}$ & $\operatorname{lgG}$ & $\mathrm{CF}-17$ \\
\hline
\end{tabular}

b

Procine cecropin P1:

$\mathrm{NH}_{2}$-OGLTLEKWKVFKKIEKMGRNIRNGIVKAGPAIAVLGEAKAL-COOH

Synthetic cecropin analog:

$\mathrm{NH}_{2}-$ KWKLFKKIALAVVGQAL-COOH

Fig. 1 a Structures of transgene constructs used to produce transgenic rainbow trout. b Amino acid sequences of porcine cecropin P1 and the synthetic cecropin analogue, CF-17. CMV cytomegalovirus promoter region, $\operatorname{Ig} G$ signal peptide sequence of catfish immunoglobulin heavy chain, cecropin $P 1$ porcine cecropin $\mathrm{P} 1$ gene, $C F-17$ synthetic cecropin analog

\section{Production of Transgenic Fish}

Sperm was collected dry from reproductive mature males and kept at $4{ }^{\circ} \mathrm{C}$ until use. Trout sperm can remain un-activated by making one to four dilutions with phosphate buffered saline (PBS: $8 \mathrm{~g} / 1 \mathrm{NaCl}, 0.2 \mathrm{~g} / \mathrm{l} \mathrm{KCl}, 1.44 \mathrm{~g} / 1 \mathrm{Na}_{2} \mathrm{HPO} 4,0.24 \mathrm{~g} / \mathrm{l}$, $\mathrm{KH}_{2} \mathrm{PO}_{4}, \mathrm{pH}$ 7.6). Mix $300 \mu \mathrm{l}$ of sperm (usually $\sim 10^{10}$ sperm/ $\mathrm{ml}$ ) gently into $600 \mu \mathrm{l}$ of linearized transgene construct (about $96 \mu \mathrm{g}$ in PBS) in a cuvette to obtain $10^{3}$ to $10^{4}$ DNA molecules/sperm. The mixture was electroporated in a "CellPorator" (BRL, Rockville, MD, USA) under the following condition: resistance, low; capacitance, 1,180 $\mu \mathrm{F}$; voltage, $300 \mathrm{~V}$; pulses, 2. After electroporation, sperm samples were kept on ice for $10 \mathrm{~min}$ to revive, and then added dropwise to 500 eggs in a 1-1 container. The eggs were swirled around several times, left at room temperature for $5 \mathrm{~min}$ and then activated with water. The fertilized eggs were poured into hatching trays and dead eggs were removed by $48 \mathrm{~h}$ after fertilization. The hatched fry were reared to adulthood for genotyping for the presence of the transgene.

Genomic DNA samples were isolated from a small piece of fin tissue collected from the caudal fin at 8 months of age and screened for the presence of transgene sequence by polymerase chain reaction (PCR) amplification and Southern blot hybridization of the PCR products (Chen et al. 1993). The primer sequences for amplification of cecropin P1 and CF-17 transgenes are listed in Table 1. The positive fish were referred to as $\mathrm{P}_{1}$ transgenic individuals. After reproductive maturation, these fish were crossed with non-transgenic counterparts to produce $F_{1}, F_{2}$ and $F_{3}$ heterozygous transgenic fish for disease challenge studies.

\section{Determination of Transgene Expression}

Expression of cecropin P1 transgene or CF-17 transgene in the individual $F_{1}, F_{2}$ or $F_{3}$ transgenic fish was determined by reverse transcription (RT)-PCR analysis. Total RNA samples were isolated from tissues of liver, muscle and spleen of transgenic individuals using Trizol reagent according to the manufacturer's protocol (Invitrogen). To confirm that RNA samples were free of DNA contamination, RNA samples were used as templates for direct PCR amplification of $\beta$-actin sequence without RT. One microgram of total RNA from transgenic or non-transgenic fish was reverse transcribed using SuperScript III reverse transcriptase in a $20-\mu$ l reaction volume containing $100 \mathrm{ng}$ oligo-dT, $1 \mathrm{mM}$ dNTP, $5 \mathrm{mM}$ DTT, $1 \times$ reaction buffer, 1 unit of RNasin (Promega, Wisconsin, USA), and $1 \mu \mathrm{l}$ of Superscript III reverse transcriptase according to the manufacture's protocol (Invitrogen). After RT, $1 \mu$ of RT mix was used for the subsequent PCR amplification in a volume of $50 \mu \mathrm{l}$ containing $200 \mu \mathrm{M}$ dNTP, $1.5 \mathrm{mM} \mathrm{MgCl}{ }_{2}, 0.3 \mu \mathrm{M}$ each gene specific primer and 1.25 units of Taq DNA polymerase (New England Biolaboratories, Massachusetts, USA). The amplification profile contained the following cycles: 1 cycle of $95{ }^{\circ} \mathrm{C}$ for $3 \mathrm{~min}, 40$ cycles of $95{ }^{\circ} \mathrm{C}$ for $15 \mathrm{~s}$, desired annealing temperature for $15 \mathrm{~s}$, and $72{ }^{\circ} \mathrm{C}$ for $30 \mathrm{~s}$. The PCR products were analyzed by electrophoresis on $1.2 \%$ agarose gels.

\section{Histological Examination}

Rainbow trout fry were infected with A. salmonicida or IHNV-RB, and the morbid fry were collected, euthanized and fixed in $10 \%$ buffered formalin $(10 \%$ formalin, $33 \mathrm{mM}$ sodium phosphate monobasic monohydrate, $46 \mathrm{mM}$ sodium phosphate dibasic heptahydrate). The fixed samples were embedded in Paraplast paraffin (Oxford Labware), and sliced sagittally into $6-\mu \mathrm{m}$ sections. The sections were placed on glass slides and stained with hematoxylin and eosin.

\section{Pathogen Challenge Studies}

Single colony of A. salmonicida was inoculated into $50 \mathrm{ml}$ of $3 \%$ tryptic soy broth (BD, Franklin Lakes, NJ, USA) containing $1 \% \mathrm{NaCl}$ (TSB) and grew at $20^{\circ} \mathrm{C}$ overnight. Then, $5 \mathrm{ml}$ of the bacterial cells from the overnight culture was inoculated into $250 \mathrm{ml}$ of fresh TSB the next day and grew for an additional $4 \mathrm{~h}$ at $20^{\circ} \mathrm{C}$ until reaching mid-log phase. The concentration of bacteria was determined by direct cell counting using a hemocytometer. Fresh IHNV stock was prepared and titer determined following the method described previously (Engelking and Leong 1981), and stored at $4{ }^{\circ} \mathrm{C}$ until use.

Three groups each of non-transgenic, $\mathrm{F}_{2}$ or $\mathrm{F}_{3}$ heterozygous transgenic fish (30 fish per each, 1-2 g/fish) were used in the challenge studies with $A$. salmonicida at the dose of $5 \times$ $10^{5}$ colony forming unit $(\mathrm{cfu}) / \mathrm{ml}$ or IHNV at the dose of $5 \times$ $10^{5}$ plaque forming unit $(\mathrm{pfu}) / \mathrm{ml}$. The challenge studies were conducted in 25-1 tanks. On the day of challenge experiment, water in each tank was drained completely and fish were stressed for $30 \mathrm{~s}$. Immediately after stressing, 11 of water containing appropriate concentration of either bacteria or virus 
Table 1 Obligonucleotide primers used in this study

\begin{tabular}{lll}
\hline Primer no. & Nucleotide sequence & Target gene \\
\hline TTC757 & {$[\mathrm{Fd}]: 5^{\prime}$-TCGTACGAGACATCAAGGAG-3' } & $\beta$-Actin \\
TTC758 & {$[\mathrm{Re}]: 5^{\prime}$-AGGAAGGAGGGCTGGAAGAG-3' } & \\
TTC921 & {$[\mathrm{Fd}]: 5^{\prime}$-CACCAAAATCAACGGGACTT-3' } & Cecropin P1 transgene \\
TTC922 & {$[\mathrm{Re}]: 5^{\prime}$-TACTCAGACAATGCGATGC-3' } & \\
TTC955 & {$[\mathrm{Fd}]: 5^{\prime}$-GCGTGGATTGCGGTTTGACT-3' } & CF-17 transgene \\
TTC956 & {$[\mathrm{Re}]: 5^{\prime}$-ATAAGAGAGCAGGGCGAGGA-3' } & \\
TTC1251 & {$[\mathrm{Fd}]: 5^{\prime}$-GCCTGCTCCTGCTCCTCGCC-3' } & mRNA of cecropin P1 \\
TTC1249 & {$[\mathrm{Re}]: 5^{\prime}$-CTGGATGGCGATGGCGATGC-3' } & \\
TTC1310 & {$[\mathrm{Fd}]: 5^{\prime}$-TCTCTACCAGCCTGCTCCTG-3' } & mRNA of CF-17 transgene \\
TTC1311 & {$[\mathrm{Re}]: 5^{\prime}$-CTAGAGGGCTTGTCCCACC-3' } & \\
TTC1367 & {$[\mathrm{Fd}]: 5^{\prime}$-TTCATATGCCAGGCTCAACA-3' } & Y chromosome specific sequence \\
TTC1368 & {$[\mathrm{Re}]: 5^{\prime}$-GCTAATGGACGACGCTTTTC-3' } & \\
\hline
\end{tabular}

was added to each tank, and the fish were kept for an additional $6 \mathrm{~h}$ with constant aeration in the tank. At the end of challenge with pathogens, aeration was stopped and air stones removed. Large volume of constant running water is flooded into each tank and fish were kept for another 4 to 6 weeks till the end of experiment. At the end of the experiment, the total numbers of survival fish were recorded and survival rates calculated to determine the mortality of each family.

\section{Production of All-Male Transgenic Fish}

All-male transgenic trout was produced following the method described by Parsons and Thorgarrd (1985). Briefly, eggs were collected from non-transgenic females, exposed to $\mathrm{Co}^{60}$ gamma radiation at a dose of $3 \times 10^{4} \mathrm{R}$. The irradiated eggs were fertilized with sperm of $\mathrm{F}_{3}$ heterozygous transgenic families. The diploidy of the fertilized eggs was restored by suppressing the first cleavage division using hydrostatic pressure and the hatched fry were reared to adulthood. The YY transgenic males were identified by PCR amplification of cecropin P1 transgene and the male was identified by PCR amplification of the Y chromosome specific sequence (Brunelli et al. 2008) using oligonucleotide primers listed in Table 1.

\section{Results}

Production, Identification and Characterization of Cecropin P1 and CF-17 Transgenic Rainbow Trout

Linearized cecropin P1 and CF-17 transgenes were transferred into rainbow trout via the sperm-mediated gene transfer method as described in Materials and Methods. The presence of transgenes in $\mathrm{P}_{1}$ presumptive transgenic animals were determined by PCR amplification of the genomic DNA isolated from fin clips (Fig. 2). About $30 \%$ of the presumptive $P_{1}$ transgenic animals were determined to carry cecropin $\mathrm{P} 1$ transgene and $25 \%$ of the presumptive transgenic animals carried CF-17 transgene, respectively. At reproductive maturation, each $\mathrm{P}_{1}$ transgenic fish was mated with counterpart non-transgenic fish to establish $\mathrm{F}_{1}$ founder families. A total of eight founder heterozygous transgenic families carrying cecropin P1 transgene and nine families carrying F-17 transgene were established. Each family of the founder fish was mated to non-transgenic fish to establish $F_{2}$ and $F_{3}$ generations.

To detect the expression of cecropin $\mathrm{P} 1$ or $\mathrm{CF}-17$ transgene in $F_{1}, F_{2}$ and $F_{3}$ generations of heterozygous transgenic progeny, total RNA samples isolated from tissues of liver, muscle and spleen were subjected RT-PCR analysis. Figure 3 shows the representative results of cecropin $\mathrm{P} 1$ transgene expression in three randomly chosen $F_{1}$ transgenic families. Transgene mRNAs were detected in tissues of liver, muscle and spleen of all eight families of cecropin P1 and nine families of CF-17 fish. To determine whether the expression of cecropin P1 transgene in transgenic fish will affect their growth performance when compared to the non-transgenic fish, the body lengths of several families of $F_{1}$ heterozygous transgenic progeny were compared with their non-transgenic counterparts. The representative result of one family is shown in Fig. 4. In this comparison, the average size of nontransgenic fish ranged about $16.0 \mathrm{~g}$ and that of transgenic fish ranged about $15.4 \mathrm{~g}$. These results might suggest the expression of cecropin P1 transgene in the transgenic fish family might not affect their growth performance when compared to non-transgenic fish.

\section{Challenge Studies with $A$. salmonicida and IHNV}

The antimicrobial activities of $\mathrm{F}_{2}$ and $\mathrm{F}_{3}$ heterozygous transgneic progeny were determined by challenging with a bacterial pathogen, $A$. salmonicida, at a dose of $5 \times 10^{5} \mathrm{cfu} / \mathrm{ml}$ and a viral pathogen, IHNV, at a dose of $5 \times 10^{5} \mathrm{pfu} / \mathrm{ml}$. In the challenge studies with $A$. salmonicida, the cumulative 
a

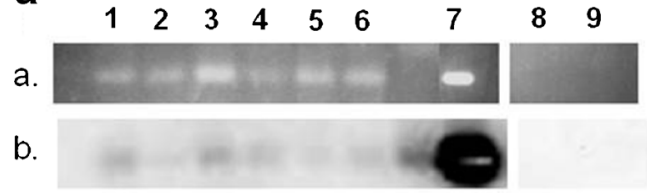

b

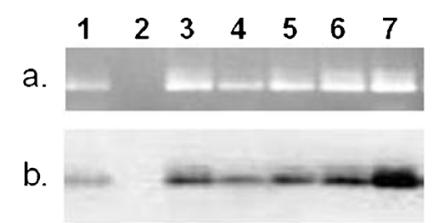

Fig. 2 Identification of transgenic rainbow trout by PCR amplification of genomic DNA from $F_{1}$ heterozygous transgenic individuals. a Detection of cecropin P1 transgene sequence. $a$ PCR products; $b$ hybridization signals of PCR products. Lanes 1-6, DNA samples from presumptive transgenic fish; lane 7, DNA of cecropin P1 transgene construct; lanes 89 , DNA from non-transgenic control fish. b Detection of CF-17 transgene sequence. $a$ PCR products; $b$ hybridization signals of PCR products. Lanes 1 and 3-6, DNA samples from presumptive transgenic fish; lane 2, DNA sample from non-transgenic control fish; lane 7, DNA of CF-17 transgene construct

mortality of control fish ranged $80-85 \%$, but the cumulative mortalities of different families of $F_{2}$ and $F_{2}$ cecropin P1 transgenic progeny ranged $12-40 \%$, except for the family of U6\#768 where the mortality was similar to that of the control fish (Table 2). When non-transgenic control fish were challenged with IHNV at the dose of $5 \times 10^{5} \mathrm{pfu} / \mathrm{ml}$, the cumulative mortality ranged $82-83 \%$, but the cumulative mortalities of $F_{2}$ and $F_{3}$ cecropin $\mathrm{P} 1$ transgenic families ranged 4-25\%, except for the family of S8\#505 where the mortality was indistinguishable from that of the nontransgenic fish (Table 3). Results of challenge studies of different $\mathrm{F}_{3}$ heterozygous CF-17 transgenic families with $A$. salmonicida and IHNV are presented in Table 4. By comparing the cumulative mortalities of non-transgenic control fish with different heterozygous families of CF-17 transgenic fish, all nine families of heterozygous CF-17 transgenic fish showed significant resistance to infection by IHNV. Similar results were observed in challenge studies with $A$. salmonicida except families 773 and 900 where challenge studies were not conducted.

The typical pathological signs were observed in morbid transgenic and non-transgenic fry challenged with $A$. salmonicida and IHNV. As shown in Fig. 5, morbid fry challenged with $A$. salmonicida displayed typical pathological signs including lesion of skin ulcers. Microscopically, focal Aeromonas samonicida microcolonies were present in multiple tissues, including liver, kidney and heart. When swabs taken sterilely from the kidney of morbid fry were plated on tryptone soy agar medium and cultured at $22^{\circ} \mathrm{C}$, the resulting colonies uniformly showed typical features of Aeromonas samonicida with convex morphology and brown pigment.

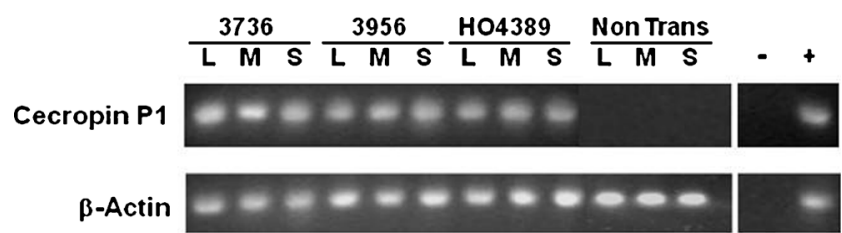

Fig. 3 Expression of cecropin P1 transgene in transgenic rainbow trout. Total RNA samples were prepared from the liver, muscle and spleen tissues of cecrpoin P1 transgenic fish (heterozygous $F_{1}$ generation), and were subjected to RT-PCR analysis for detection of cecropin P1 transcript following the method described in Materials and Methods. 3736, 3956 and HO4389 are randomly selected $\mathrm{F}_{1}$ heterozygous transgenic fish. $L$ liver, $M$ muscle, $S$ spleen; +, plasmid DNA contains cecropin P1 sequence for positive control in PCR; -, PCR reaction in the absence of cecropin P1 DNA

While typical pathological signs including distended abdomen, petechial hemorrhages and exophthalmos were observed in morbid fry challenged with IHNV, microscopic observation revealed extensive necrosis in the internal organs including kidney and liver (Fig. 6).

\section{Development of All-Male Transgenic Rainbow Trout}

All-male homozygous cecropin P1 transgenic fish strains were bred from $\mathrm{F}_{3}$ heterozygous transgenic fish by using the technique of androgenesis developed by Parsons and Thorgarrd (1985). Eight families (S7\#375-F073, S9\#659F180, S9\#746-F509, U6\#768-G410, S8\#505-G231, S7\#342F695, A12-944 and A13-831) of all-male homozygous cecropin P1 transgenic fish were successfully bred. Although female transgenic fish were also produced in this operation, these fish were discarded since these fish produced poor quality eggs according to studies by Scheerer et al.

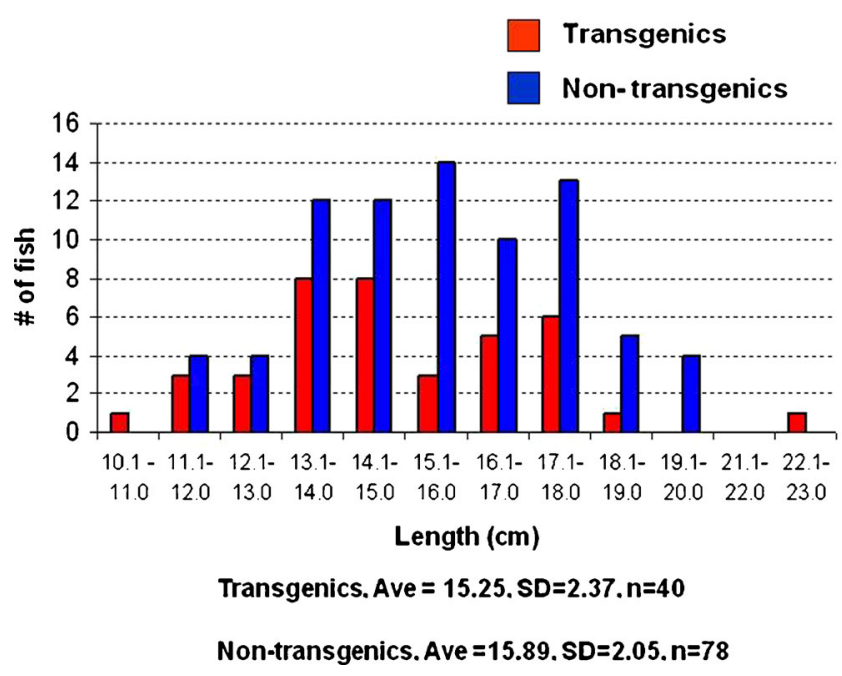

Fig. 4 Body size distribution of transgenic and non-transgenic fish. The body sizes of cecropin $\mathrm{P} 1$ heterozygous transgenic fish ( $\mathrm{F}_{1}$ generation) and their non-transgenic sibling controls were measured and grouped into different size classes 
Table 2 Mortalities of $F_{2}$ and $F_{3}$ heterozygous cecropin P1 transgenic fish challenged with $A$. salmonicida

\begin{tabular}{lll}
\hline Families & \multicolumn{2}{l}{$\%$ Mortality $($ mean $\pm \mathrm{SD})$} \\
\cline { 2 - 3 } & $\mathrm{F}_{2}$ generation & $\mathrm{F}_{3}$ generation \\
\hline S8\#Y419 & $12 \pm 3$ & $15 \pm 5$ \\
S7\#375 & $14 \pm 5$ & $18 \pm 8$ \\
S9\#746 & $20 \pm 6$ & $30 \pm 5$ \\
S7\#342 & $30 \pm 3$ & $35 \pm 4$ \\
S8\#505 & $20 \pm 4$ & $26 \pm 8$ \\
S9\#638 & $10 \pm 2$ & $14 \pm 8$ \\
S9\#659 & $25 \pm 6$ & $40 \pm 10$ \\
U6\#768 & $80 \pm 3$ & $79 \pm 12$ \\
Non-transgenic & $80 \pm 6$ & $85 \pm 8$ \\
\hline
\end{tabular}

For each family, challenge was conducted with 30 fish/family (1-2 g body weight)in triplicates and the dose of A. salmonicida $\left(5 \times 10^{5} \mathrm{cfu} / \mathrm{ml}\right)$ used in each challenge study brings about $80 \%$ mortality in non-transgenic fish

(1991). The expression of cecropin P1 transgene in heart, liver, muscle and spleen tissues of six selected homozygous families was confirmed by RT-PCR analysis. As shown in Fig. 7, various levels of cecropin P1 mRNA were detected in these tissues. Two selected families (namely S7\#375-F073 and S7\#659-F180) of cecropin P1 homozygous all-male fish were outcrossed to non-transgenic females and their heterozygous progeny were subjected to challenge studies with $A$. salmonicida at the concentrations of $1 \times 10^{5}$ and $5 \times 10^{5} \mathrm{cfu} /$ $\mathrm{ml}$, and the results of the challenge studies were presented in Fig. 8. Persistent resistant characteristic to A. salmonicida infection was observed in the heterozygous fish derived from both homozygous families out cross to non-transgenic fish.

Table 3 Mortalities of $\mathrm{F}_{2}$ and $\mathrm{F}_{3}$ heterozygous cecropin P1 transgenic fish challenged with $I H N V$

\begin{tabular}{lll}
\hline Families & \multicolumn{2}{l}{$\%$ Mortality $($ mean $\pm \mathrm{SD})$} \\
\cline { 2 - 3 } & $\mathrm{F}_{2}$ generation & $\mathrm{F}_{3}$ generation \\
\hline S8\#Y419 & $25 \pm 3$ & $20 \pm 6$ \\
S7\#375 & $20 \pm 5$ & $18 \pm 6$ \\
S9\#746 & $4 \pm 2$ & $10 \pm 5$ \\
S7\#342 & $15 \pm 3$ & $17 \pm 4$ \\
S8\#505 & $79 \pm 8$ & $82 \pm 4$ \\
S9\#638 & $12 \pm 2$ & $11 \pm 8$ \\
S9\#659 & $20 \pm 6$ & $25 \pm 9$ \\
U6\#768 & $18 \pm 5$ & $25 \pm 5$ \\
Non-transgenic & $82 \pm 6$ & $83 \pm 8$ \\
\hline
\end{tabular}

For each family, challenge was conducted in 30 fish/family (1-2 $\mathrm{g}$ body weight)in triplicates and the dose of IHNV $\left(5 \times 10^{5} \mathrm{pfu} / \mathrm{ml}\right)$ used in each challenge study brings about $80 \%$ mortality in non-transgenic fish
Table 4 Mortalities of $\mathrm{F}_{3}$ heterozygous $\mathrm{CF}-17$ transgenic rainbow trout challenged with $A$. salmonicida or IHNV

\begin{tabular}{lcc}
\hline Families & \multicolumn{2}{c}{$\%$ Mortality (mean \pm SD } \\
\cline { 2 - 3 } & A. salmonicida & IHNV \\
\hline 711 & $15 \pm 5$ & $12 \pm 2$ \\
756 & $40 \pm 6$ & $20 \pm 4$ \\
773 & - & $20 \pm 2$ \\
829 & $30 \pm 6$ & $20 \pm 3$ \\
850 & $40 \pm 4$ & $40 \pm 5$ \\
887 & $55 \pm 7$ & $20 \pm 4$ \\
900 & - & $15 \pm 2$ \\
908 & $20 \pm 2$ & $25 \pm 2$ \\
921 & $20 \pm 3$ & $20 \pm 1$ \\
Non-transgenic & $85 \pm 4$ & $82 \pm 2$ \\
\hline
\end{tabular}

For each family, challenge was conducted with 30 fish/family (1-2 g body weight)in triplicates and the dose of $A$. samonicida $\left(5 \times 10^{5} \mathrm{cfu} /\right.$ $\mathrm{ml})$ or $\operatorname{IHNV}\left(5 \times 10^{5} \mathrm{pfu} / \mathrm{ml}\right)$ in each challenge study brings about $80 \%$ mortality in non-transgenic fish

- not tested

\section{Discussion}

In aquaculture industry worldwide, bacterial and viral diseases result in tremendous economic losses annually. Current strategies to control these diseases consist of prophylaxis such as vaccination with inactivated pathogens or recombinant vaccines, medication with chemicals or antibiotics, and eradication of infected populations. Although effective vaccines have

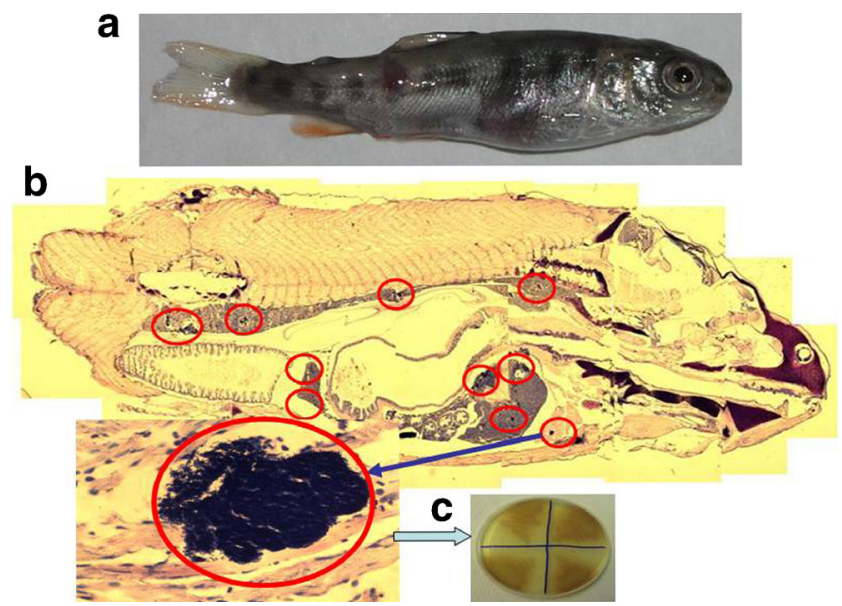

Fig. 5 Fry of non-transgenic rainbow trout infected with $A$. salmonicida exhibited typical pathological signs. Morbid fry showed typical lesion of skin ulcer (a). Microscopically, focal A. salmonicida microcolonies (indicated by red circles) were present in multiple tissues, including liver and kidney (b). Occasionally, the bacteria microcolonies were observed in the heart (inset in b). Swabs taken sterilely from the kidney of morbid fry were plated on tryptone soy agar $(T S A)$ and incubated at $22^{\circ} \mathrm{C}$. The colonies uniformly showed typical features of $A$. salmonicida with convex morphology and brown pigment (c) 
Fig. 6 Fry of non-transgenic rainbow trout infected with IHNV exhibited typical pathological signs. a Morbid fry showed clinical signs typical to the IHNV disease, including distended abdomen, petechial hemorrhages, and exophthalmos.

Microscopically, extensive necrosis was observed in the internal organs, including kidney (b) and liver (c)

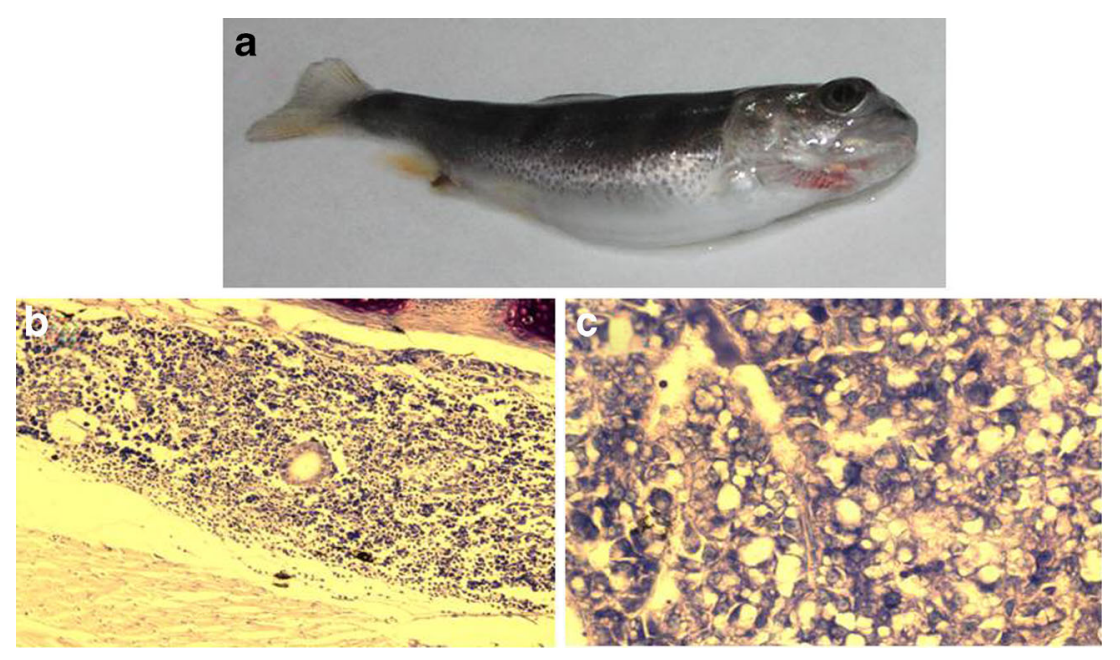

been developed for selective important fish pathogens over the past decades, the economic cost of developing vaccines and the labor intensiveness of vaccination practice frequently out-weigh the economic benefits. Furthermore, the potential risk of residual levels of antibiotics left in the flesh of fish and the selection of antibiotic-resistant bacterial strains in the aquatic environment argues against the benefit of using antibiotics to control fish diseases. If a genetic trait that will confer fish to be resistant to bacterial, viral or parasitic infection can be identified, manipulation of this genetic trait by transgenesis may present a unique opportunity to resolve the problem of disease outbreak in aquaculture. What genetic trait may confer fish resistant to infection by pathogens?

It has long been recognized that both innate and adaptive immunity systems are required for fish and higher animals to overcome infection by microbial pathogens. While adaptive immunity can protect the host from infection by specific microbial pathogens, it usually requires a longer period of time for the host to develop antigen-specific antibodies and immunologic memory against the specific pathogen. Since fish are living under a lower temperature environment compared to mammals, it will require a longer period of time to develop adaptive immunity to control the initial phase of infection by microbial pathogens (Boman 1995; Bonizzi and Karin 2004). The innate immunity system could serve as the first line of defense to eliminate primary infection by microbial pathogens because the host produces antimicrobial peptides or other small molecular weight compounds with antimicrobial activities within hours upon exposure to pathogens (Boman 1995). Since the identification of the first insect antimicrobial peptides, cecropins, a large body of similar antimicrobial peptides has been identified in a wide variety of organisms throughout the animal kingdom (Hultmark et al. 1980; Boman and Hultmark 1987; Destoumieux et al. 1997; Chiou et al. 2005; Pillai et al. 2005; Syvitski et al. 2005). In vitro and in vivo studies showed that these peptides possess activities against a broad spectrum of fish bacterial viral pathogens (Boman 1995; Hancock and Lehrer 1998; Jia et al. 2000; Chiou et al. 2002; Sarmasik et al. 2002). Studies have also been reported that transfer of functional cecropin $\mathrm{B}$ gene into plants resulted in the production of transgenic plants with elevated resistance to bacterial pathogens (Jaynes et al. 1987; Hassan et al. 1993; Jia et al. 1993; Huang et al. 1997; Osusky et al. 2000). These results suggest that transgenic manipulation of antimicrobial peptide genes may lead to the production of fish strains with elevated resistance to bacterial and viral pathogens.

To test this hypothesis, Sarmasik et al. (2002) introduced transgenes of pre-pro-cecropin $\mathrm{B}$, pro-cecropin $\mathrm{B}$, mature cecropin $\mathrm{B}$ and cecropin $\mathrm{P} 1$ driven by a CMV promoter into Japanese medaka (Orizias latipas). The resulting $\mathrm{F}_{2}$ transgenic progeny displayed significant resistance to $P$. fluorescens and $V$. anguillarum in repeated challenge studies. Like transgenic plants expressing antimicrobial peptide genes (Jaynes

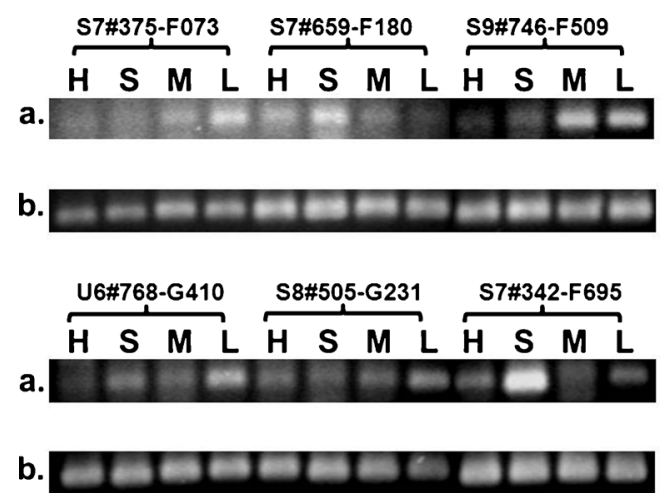

Fig. 7 Detection of cecropin P1 transgene expression in homozygous transgenic fish by RT-PCR analysis. a RT-PCR products of cecropin P1 transgene; $\mathbf{b}$ RT-PCR product of $\beta$-actin gene. Total RNA samples were prepared from tissues of heart, spleen, muscle and liver and subjected to RT-PCR analysis for the expression of cecropin P1 transgene following methods described in Materials and Methods. $H$ heart, $S$ spleen, $M$ muscle, $L$ liver 


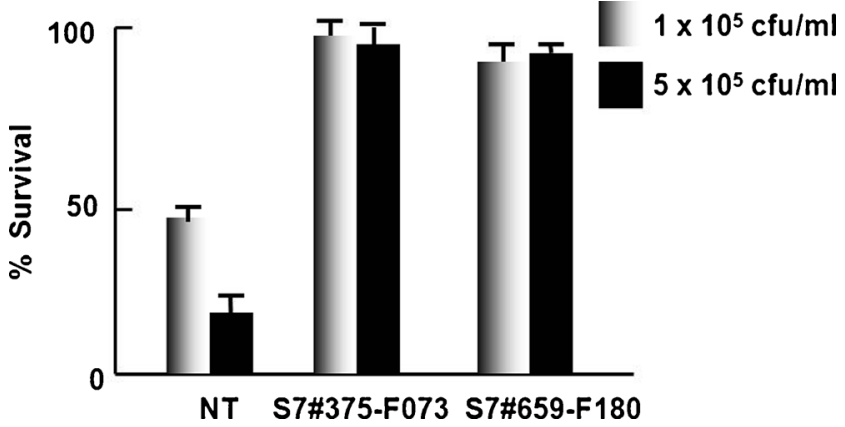

Fig. 8 Percent survival of heterozygous cecropin P1 transgenic fish derived from all-male homozygous fish challenged with Aeromonas salmonicida. Triplicate families of heterozygous transgenic fish progeny (50 fish/family of $0.4-0.5 \mathrm{~g}$ body weight) and non-transgenic controls were challenged with $A$. salmonicida at doses of $1 \times 10^{5}$ and $5 \times 10^{5} \mathrm{cfu} /$ $\mathrm{ml}$ as described in Materials and Methods. Morbid fish were collected daily over a period of 2 weeks post-challenge with the pathogen

et al. 1987; Hassan et al. 1993; Jia et al. 1993; Huang et al. 1997; Osusky et al. 2000), transgenic medaka expressing cecropin B or cecropin P1 transgene displayed resistant characteristic to common fish bacterial pathogens.

Will an aquaculture important fish species exhibit the similar resistant characteristic to common fish bacterial pathogens if a cecropin B or cecropin P1 transgene is introduced into the fish by transgenesis? To answer this question, we produced transgenic rainbow trout carrying cecropin P1 or CF-17 transgene fused to the CMV promoter by sperm mediated gene transfer method. PCR analysis of the presumptive $\mathrm{P}_{1}$ transgenic fish showed that about $30 \%$ of the presumptive $\mathrm{P}_{1}$ transgenic animals carried the cecropin P1 transgene and $25 \%$ carried the CF-17 transgene. These results are consistent with those reported by other investigators (Powers et al. 1992; Symonds et al. 1994; Sin et al. 2000; Lu et al. 2002). A total of eight $F_{1}$ founder heterozygous transgenic families carrying cecropin $\mathrm{P} 1$ transgene and nine $\mathrm{F}_{1}$ heterozygous families carrying CF-17 transgene were established, respectively. Results of RT-PCR analysis confirmed the expression of cecropin $\mathrm{P} 1$ and $\mathrm{CF}-17$ transgenes in $\mathrm{F}_{1}, \mathrm{~F}_{2}$ and $\mathrm{F}_{3}$ heterozygous transgenic progeny.

Fish digestive tract, like the digestive tract of human, is inhabited by large numbers of pathogenic and non-pathogenic microorganisms (Cummings and Macfarlans 1997; Guarner and Malagelada 2005; Ray et al. 2012; Sanchez et al. 2012). Many of these non-pathogenic microorganisms contribute greatly to the digestion of foods, supplying vitamin B complex and other essential nutrients, and enhancing absorption of nutrients by the fish gut (Ray et al. 2012; Sanchez et al. 2012). Since antimicrobial peptides possess bactericidal activity to a large spectrum of microorganisms, it is conceivable that cecropin P1 and CF-17 transgene expressed in the transgenic fish may kill the beneficial microorganisms in the gut and thus affect the growth performance of the fish. When the patterns of body size distribution of several $F_{1}$ heterozygous transgenic families expressing cecropin P1 transgene were compared to that of non-transgenic siblings, the patterns of body size distribution of transgenic fish were not significantly different from to those of the non-transgenic fish. These results suggest that the expression of cecropin P1 transgene in the transgenic fish may not affect the population of the beneficial microorganisms inhabiting in the fish digestive system. Similar observation has also been reported by Dunham et al. (2002) in $F_{1}$ heterozygous transgenic channel catfish (Ictalurus punctatus) expressing cecropin transgenes.

Types of pathogens, routes of pathogen entry, and the virulence of pathogens are three critical factors in pathogen challenge studies (Michel 1980; Adams et al. 1987). Since $A$. salmonicida and IHNV are two well-recognized aggressive pathogens infecting salmonid fish species, we chose these two organisms as target pathogens for the challenge studies to determine the antimicrobial activity of cecropin P1 and CF17 transgenic fish. In the challenge studies, $A$. salmonicida at the concentration of $5 \times 10^{5} \mathrm{cfu} / \mathrm{ml}$ or IHNV at the concentration of $5 \times 10^{5} \mathrm{pfu} / \mathrm{ml}$ were introduced into fish of $1-2 \mathrm{~g}$ body weight by immersion because this method could provide the most natural route of pathogen entry into the fish (McCarthy 1983; Hjeltnes et al. 1989). In repeated challenge studies, while exposure of non-transgenic fish to $5 \times 10^{5} \mathrm{cfu} / \mathrm{ml}$ of $A$. salmonicida or $5 \times 10^{5} \mathrm{cfu} / \mathrm{ml}$ of IHNV resulted in about $80 \%$ of cumulative mortality, exposure of $F_{2}$ or $F_{3}$ transgenic families of cecropin $\mathrm{P} 1$ transgenic fish to A. salmonicida brought about 10-40\% cumulative mortalities and 4-20\% cumulative mortalities to IHNV. Similar degrees of protection from infection by both pathogens were also observed in CF-17 transgenic families. It is of interesting to note that while most families of $F_{2}$ and $F_{3}$ cecropin $P 1$ transgenic fish displayed resistant characteristic to both pathogens, family U6\#768 failed to show resistant characteristic to A. salmonicida and family S8\#505 failed to display resistant characteristic to IHNV even though both families expressed cecropin P1 transgene. The reason for this dichotomy requires further investigation. Nevertheless, the overall results from the current study are in good agreement with the in vitro studies reported by Chiou et al. (2002) where they reported that synthetic cecropin $\mathrm{B}$ and CF-17 were effective in killing A. salmonicida and various fish RNA viruses including IHNV.

In summary, we demonstrated in this study the production of strains of stable transgenic rainbow trout expressing cecropin P1 or CF-17 transgene by sperm-mediated gene transfer method. These transgenic fish displayed elevated resistant characteristic to infection by $A$. salmonicida and IHNV. By employing the technique of androgenesis, homozygous all-male (YY) transgenic families have been bred in one generation; and these transgenic stocks can be preserved via sperm cryopreservation. Dunham et al. (2002) reported previously the production of transgenic channel catfish (Ictalurus punctatus) harboring cecropin B transgenes 
exhibiting elevated resistant to bacterial pathogen in the $\mathrm{F}_{1}$ generation. Therefore, results presented in this paper, together with those of Dunham et al. (2002), clearly point to the possibility of producing disease-resistant fish strains for aquaculture by transgenic manipulation of antimicrobial peptide genes.

Acknowledgments We thank Dr. Rex Dunham of Auburn University for providing cecropin P1 transgene construct, Ms. Harriet Lorz at OSU for her assistance on sample preparation for histology examination and $\mathrm{Mr}$. Don Stevens for his assistance on the rearing of transgenic trout at the SDL of OSU. This work was supported by grants from the U.S. Department of Agriculture (CONTR 58-1930-5-522, CONTR58-1930-0-009 and CONS-9803641) to TTC

Open Access This article is distributed under the terms of the Creative Commons Attribution License which permits any use, distribution, and reproduction in any medium, provided the original author(s) and the source are credited.

\section{References}

Adams A, Leschen W, Wilson A, Horne MT (1987) A bath challenge model for frunculosis in rainbow trout, Salmo gairdneri Richardson, and Atlantic Salmon, Salmo salar L. J Fish Dis 10:495-504

Bechinger B (1997) Structures and functions of channel-forming peptides: magainins, cecropins, melitin and alamethicin. J Memr (United States) 156:197-211

Boman HG (1995) Peptide antibiotics and their roles in innate immunity. Annu Rev Immunol 13:61-92

Boman HG, Hultmark D (1987) Cell-free immunity in insects. Ann Rev Microl 41:103-125

Boman HG, Faye I, Gudmundsson GH, Jung-Youn L, Lidholm D-A (1991) Cell-free immunity in cecropina. Eur J Biochem 201:23-31

Bonizzi G, Karin M (2004) The two NF-kB activation pathways and their role in innate and adaptive immunity. Trends Immunol 25:280-288

Broekaert WE, Terras FRG, Cammue BPA, Osborn RW (1995) Plant defensins: novel antimicrobial peptides as components of host defense system. Plant Physiol 108:1353-1358

Brunelli JP, Wertzler KJ, Sundin K, Thorgaard GH (2008) Y-specific sequences and polymorphisms in rainbow trout and Chinook salmon. Genome 51:739-748

Bulet P, Stocklin R, Menin L (2004) Anti-microbial peptides: from invertebrates to vertebrates. Immunol Rev 198:161-184

Chen TT, Powers DA, Lin CM, Kight K, Hayat M, Chatakondi N, Ramboux AC, Duncan PL, Dunham RA (1993) Expression and inheritance of RSVLTR-rtGH1 cDNA in common carp, Cyprinus carpio. Mol Mar Biol Biotechnol 2:88-95

Chiou PP, Lin C-M, Perez L, Chen TT (2002) Effect of cecropin B and a synthetic analog on propagation of fish viruses in vitro. Marine Biotechnol 4:294-302

Chiou TT, Wu JL, Chen TT, Lu JK (2005) Molecular cloning and characterization of cDNA of penaeidin-like antimicrobial peptide from tiger shrimp (Penaeus monodon). Mar Biotechnol 7:119-127

Chiou PP, Bols N, Douglas S, Chen TT (2006) Regulation of immunerelevant genes in the trout macrophage cell line RTS11 by antimicrobial peptides. Dev Comp Immunol 30:797-806

Cummings JH, Macfarlans GT (1997) Role of intestinal bacteria in nutrient metabolism. Clin Nutr 16:3-11

Destoumieux D, Bulet P, Loew D, Van Doresselear A, Rodriguez J, Baechere E (1997) Penaeidins: a new family of antimicrobial peptides in the shrimp, Penaeus vannamei Decapoda. J Biol Chem 272: 28398-28406
Dunham RA, Warr G, Nichols A, Duncan P, Argue B, Middleton D, Liu $Z$ (2002) Enhanced bacterial disease resistance of teransgenic channel catfish, Ictalurus punctatus, possessing cecropin genes. Mar Biotechnol 4:338-344

Engelking HM, Leong JC (1981) IHNV persistently infects Chinook salmon embryo cells. Virol 190:47-58

Fjalestad KT, Gjedrem T, Gjerde B (1993) Genetic improvement of disease resistance in fish: an overview. Aquaculture 111:65-74

Ganz T (1999) Defensins and host defense. Science 286:420-421

Guarner F, Malagelada JR (2005) Gut flora in health and disease. Lancet 360:512-519

Hancock RE, Lehrer R (1998) Cationic peptides: a new source of antibiotics. Tibtech 16:82-87

Hassan M, Siden SL, Kobayashi SJ, Nordeen RO, Owens LD (1993) Transformation of potato (Salanum tuberosum) with a gene for an antibacterial protein, cecropin. Acta Horticult 336:127-131

Hjeltnes B, Andersen K, Ellisen H-M (1989) Vaccination against $A$. salmonicida: the effect of different routes of administration and revaccination. Aquaculture 83:1-6

Huang Y, Nordeen RO, Di LD, McBeath JH (1997) Expression of an engineered cecropin gene cassette in transgenic tobacco plant confers disease resistant to Pseudomonas syringae pv. tabaci. Phytopathology 87:4494-499

Hultmark D, Steiner H, Rusmuson T, Boman HG (1980) Insect immunity: purification and properties of three inducible bactericidal proteins from hemolymph of immunized pupae of Hyalophora cecropia. Eur J Biochem 106:7-16

Inglis V, Hendrie MS (1993) Pseudomonas and Aeromonas infections. In: Ingislis V, Roberts R, Bromage NR (eds) Bacterial diseases of fish. Halsted Press, New York, pp 167-169

Jaynes JM, Xanthopoulos KG, Destefano-Boltran L, Dodds JH (1987) Increasing bacterial disease resistance utilizing antibacterial genes from insects. Bioessays 6:263-270

Jia SR, Xie Y, Tang T, Feng IX, Cao DS, Zhao YL, Yuan J, Bai YY, Jiang CX Jaynes JM (1993) Genetic engineering of Chinese potato cultivars by introducing antibacterial polypeptide gene. Agriculture 15: 205-212

Jia A, Patrzykat A, Devlin RH, Ackerman PA, Iwama GK, Hancock RE (2000) Antimicrobial peptides protect coho salmon from Vibrio anguillarum infections. Appl Environ Microbiol 66:1928-1932

Kadonon-Okuda E, Taniai K, Kato Y, Kotani E, Yamakawa M (1995) Effect of synthetic Bombyx mori cecropin B on the growth of plant pathogenic bacteria. J Invertebr Pathol (United States) 65:309-310

Lu JK, Fu BH, Wu JL, Chen TT (2002) Production of transgenic silver sea bream (Sparus sarba) by different gene transfer methods. Mar Biotechnol 4:328-337

McCarthy DH (1983) An experimental model for fish frunculosis caused by Aeromonas salmonicioda. J Fish Dis 6:231-237

Merrifield EL, Michell SA, Ubach J, Boman HG, Andreu D, Merrifield RB (1995) D-Enantiomers of 15-residue cecropin A-melitin hybrids. Int J Pept Protein Res (Denmark) 46:214-220

Michel C (1980) A standardized model experimental frunculosis in rainbow trout (Salmo garidneri). Can J Aquat Sci 37:746-750

Osusky M, Zhou G, Osuska L, Hancock RE, Kay WW, Misra S (2000) Transgenic plants expressing cationic peptide chimera exhibit broad-spectrum resistance to phytopathogens. Nature Biotechnol 16:1162-1166

Parsons JE, Thorgarrd GH (1985) Production of androgenic diploid rainbow trout. J Hered 76:177-181

Pillai A, Ueno S, Zhang H, Lee JM, Kato Y (2005) Cecropin P1 and novel nematode cecropin: a bacteria-inducible antimicrobial peptide family in the nematode Ascaris suum. Biochem J 390:207-214

Post G (1987) Textbook of fish Health. TFH Publications, Inc, Neptune City

Powers DA, Hereford L, Cole T, Crech K, Chen TT, Lin CM, Kight K, Dunham RA (1992) Electroporation: a method for transferring genes into gametes of zebrafish (Brachydanio rerio), channel catfish 
(Ictalurus punctatus), and common carp (Cyrinus carpio). Mol Mar Biol Biotechnol 1:301-308

Ray AK, Ghosh K, Ringo F (2012) Enzyme-producing bacteria isolated from fish gut: a review. Aqua Nutri 18:465-492

Rodriguez MC, Zambudio F, Torres JA, Gonzalez-Cerone L, Posani LD, Rodriguez MH (1995) Effect of cecropin-like synthetic peptide (Shiva-3) on the sporogonic development of Plasmodium berghei. Exp Parasitol (United States) 80:596-604

Sanchez LM, Wong WR, Riener RM, Schulze CJ, Linington RG (2012) Examining the fish microbiome: vertebrate-derived bacteria as an environmental niche for the discovery of unique marine natural products. PLos One 7:11-16

Sarmasik A, Chen TT (2003) Bactericidal activity of cecropin B and cecropin P1 expressed in fish cells (CHSE-214): application in controlling fish bacterial pathogens. Aquaculture 220:183-184

Sarmasik S, Warr G, Chen TT (2002) Production of transgenic medaka with increased resistance to bacterial pathogens. Mar Biotechnol 4: 310-322

Scheerer PD, Thogaard GH, Allendorf FW (1991) Genetic analysis of androgenetic rainbow trout. J Exp Zool 260:382-390

Sin FY, Walker SP, Symond JE, Mukherjee UK, Khoo JG, Sin IL (2000) Electroporation of salmon sperm for gene transfer: efficiency, reliability, and fate of transgene. Mol Reprod Dev 56(2 Suppl):285-288

Symonds JE, Walker SP, Sin FY (1994) Development of mass gene transfer method in Chinook salmon: optimization of gene transfer by electroporated sperm. Mol Mar Biol Biotechnol 3:104 111

Syvitski RT, Burton I, Mattatall NR, Douglas SE, Jakeman DL (2005) Structural characterization of the antimicrobial peptides pleurocidin from winter flounder. Biochemistry 44:7282-7293

Thune RL, Stanley LA, Cooper RK (1993) Pathogenesis of gram-negative bacterial infections in warmwater fish. Annu Rev Fish Dis 3:37-68

Tian C, Gao B, Fang Q, Ye G, Zhu S (2010) Antimicrobial peptide-like genes in Nasonia vitripennis: a genomic perspective. BMC Genomics 11:224

van Hofsten P, Faye I, Kockum K, Lee J-Y, Xanthopoulos KG, Boman IA, Boman HG, Engstrom A, Andreu D, Merrifield RB (1985) Molecular cloning, cDNA sequencing, and chemical synthesis of cecropin B from Hyalophora cecropia. Proc Natl Acad Sci U S A 82:2240-2243

Vunnam S, Juvvadi P, Merrifield RB (1995) Synthesis and antibacterial action of cecropin and prolin- arginine-rich peptides from pig intestine. J Pept Res (Denmark) 49:59-66 